\title{
Skeletal muscle deiodinase type 2 regulation during illness in mice
}

\author{
J Kwakkel, H C van Beeren, M T Ackermans', M C Platvoet-ter Schiphorst, E Fliers, \\ W M Wiersinga and A Boelen \\ Department of Endocrinology and Metabolism, ${ }^{1}$ Laboratory of Endocrinology, Department of Clinical Chemistry, Academic Medical Center, University of \\ Amsterdam, F5-165, Meibergdreef 9, 1105 AZ Amsterdam, The Netherlands \\ (Correspondence should be addressed to J Kwakkel; Email: g.j.kwakkel@amc.uva.nl)
}

\begin{abstract}
We have previously shown that skeletal muscle deiodinase type 2 (D2) mRNA (listed as Dio2 in MGI Database) is upregulated in an animal model of acute illness. However, human studies on the expression of muscle D2 during illness report conflicting data. Therefore, we evaluated the expression of skeletal muscle D2 and D2-regulating factors in two mouse models of illness that differ in timing and severity of illness: 1) turpentine-induced inflammation, and 2) Streptococcus pneumoniae infection. During turpentineinduced inflammation, D2 mRNA and activity increased compared to pair-fed controls, most prominently at day 1 and 2, whereas after $S$. pneumoniae infection D2 mRNA decreased. We evaluated the association of D2 expression with serum thyroid hormones, (de-)ubiquitinating enzymes ubiquitin-specific peptidase 33 and WD repeat and SOCS box-containing 1 (Wsb1), cytokine expression and activation of inflammatory pathways and cAMP pathway.
\end{abstract}

During chronic inflammation the increased muscle D2 expression is associated with the activation of the cAMP pathway. The normalization of D2 5 days after turpentine injection coincides with increased $W s b 1$ and tumor necrosis factor $\alpha$ expression. Muscle interleukin-1 $\beta$ (Il1b) expression correlated with decreased D2 mRNA expression after $S$. pneumoniae infection. In conclusion, muscle D2 expression is differentially regulated during illness, probably related to differences in the inflammatory response and type of pathology. D2 mRNA and activity increases in skeletal muscle during the acute phase of chronic inflammation compared to pair-fed controls probably due to activation of the cAMP pathway. In contrast, muscle D2 mRNA decreases $48 \mathrm{~h}$ after a severe bacterial infection, which is associated with local $I l 1 \mathrm{~b}$ mRNA expression and might also be due to diminished food-intake.

Journal of Endocrinology (2009) 203, 263-270

\section{Introduction}

During illness, the central and peripheral thyroid hormone metabolism changes profoundly. This is known as non-thyroidal illness syndrome (NTIS). NTIS is characterized by decreased serum tri-iodothyronine $\left(T_{3}\right)$ levels, while TSH remains unchanged or even decreases. Furthermore, the expression of deiodinating enzymes changes in various tissues (Wiersinga 2005). Deiodinase type 2 (D2; listed as Dio2 in MGI Database) is one of the three known deiodinases. It converts the prohormone thyroxine $\left(T_{4}\right)$ into the active hormone $T_{3}$ by outer-ring deiodination. D2 is expressed in brain, pituitary, skeletal muscle, brown adipose tissue, and placenta and is present as an active dimer in the endoplasmic reticulum (Kohrle 2000, Bianco \& Kim 2006).

Recently it has been shown that skeletal muscle D2 is involved in the peripheral production of $\mathrm{T}_{3}$ under normal circumstances (Maia et al. 2005), which makes D2 a possible factor contributing to the low serum $\mathrm{T}_{3}$ levels during illness. A study of Rodriguez-Perez et al. (2008) indeed reports decreased muscle $D 2$ mRNA and activity in septic patients. In contrast, D2 mRNA and activity were upregulated in muscles of intensive care unit (ICU) -patients compared to healthy controls (Mebis et al. 2007), in line with our previous finding that muscle D2 mRNA is increased after LPS administration in mice (Kwakkel et al. 2008).

D2 expression is known to be influenced by thyroid hormone levels. $\mathrm{T}_{3}$ downregulates $\mathrm{D} 2$ mRNA expression (Burmeister et al. 1997), and $\mathrm{T}_{4}$ and reverse $\mathrm{T}_{3}\left(\mathrm{rT}_{3}\right)$ (the substrates of D2) subsequently increase D2 ubiquitination and proteasomal degradation, resulting in decreased D2 activity. The ubiquitin ligase adaptor WD repeat and SOCS boxcontaining 1 (Wsb1) is involved in the ubiquitination process of D2, whereas ubiquitin-specific peptidase 33 (Usp33) is a de-ubiquitinating enzyme (Sagar et al. 2007).

cAMP activation stimulates D2 expression on mRNA and activity level. D2 mRNA is upregulated via the CREB responsive element present in the D2 promoter and cAMP inhibits Wsb1 mediated ubiquitination of D2 (Bartha et al. 2000, Dentice et al. 2007). 
Proinflammatory cytokines are also capable of affecting D2; Hosoi et al. (1999) showed that tumor necrosis factor $\alpha(T n f)$ reduced the forskolin-induced increase of D2 mRNA and activity in skeletal muscle cells. Proinflammatory cytokines exert their actions via specific signal transduction pathways, such as nuclear factor $(\mathrm{NF}) \kappa \mathrm{B}$, extracellular-signal related kinase (ERK)1/2 and activator protein-1 (AP-1). $\mathrm{NF \kappa B}$ and AP-1 sites have been characterized in the D2 promoter (Gereben \& Salvatore 2005, Zeold et al. 2006), suggesting that activation of these pathways results in changes in D2 expression.

The aim of the present study was to evaluate the association between D2 expression and D2 regulating factors during illness. To this end, we used two animal models that differ in acute phase response, timing, and severity of illness. 1) Turpentine-induced abscess in the hindlimb, a model of local chronic inflammation. 2) Streptococcus pneumoniae infection, a lethal model that results in severe pneumonia and sepsis. Muscle D2 expression and D2 regulatory factors were evaluated in both models.

\section{Materials and Methods}

\section{Animal experiments}

Female C57Bl6 mice (Harlan Spraque-Dawley, Horst, The Netherlands) were used at $6-12$ weeks of age. The mice were kept in $12 \mathrm{~h}$ light: $12 \mathrm{~h}$ darkness cycles in a temperaturecontrolled room.

A week before the experiment the animals were housed in groups according to the experimental setup.

Turpentine injection Local chronic inflammation was induced by s.c. injection of $100 \mu \mathrm{l}$ steam-distilled turpentine in each hindlimb. Control mice received $100 \mu \mathrm{l}$ saline in each hindlimb and were pair-fed, because the decreased foodintake 1 and 2 days after turpentine injection affects thyroid hormone metabolism. The pair-fed control mice $(5$ mice per cage) received $5 \mathrm{~g} /$ cage at day $1,5 \mathrm{~g} /$ cage at day $2,8 \mathrm{~g} /$ cage at day $3,12 \mathrm{~g} /$ cage at day 4 , and $16 \mathrm{~g} /$ cage at day 5 . Normal food intake is $\sim 20 \mathrm{~g} /$ cage. The mean decrease in weight was 9.3\% (turpentine) and $9 \cdot 4 \%$ (pair-fed controls) at day 1 ; $12 \cdot 4 \%$ (turpentine) and $12.7 \%$ (pair-fed controls) at day 2 ; $2 \cdot 3 \%$ (turpentine) and $8 \cdot 6 \%$ (pair-fed controls) at day 5 . At days $0,1,2$, and 5 four to five mice per group were anaesthetized with isoflurane. Blood was taken by cardiac puncture and the mice were subsequently killed by cervical dislocation. Serum was stored at $-20{ }^{\circ} \mathrm{C}$ until analysis. Turpentine injection resulted in a sterile abscess, infiltrating cells at the site of injection and a decrease in serum thyroid hormone levels as previously described (Boelen et al. 2006a). Because the abscess and infiltrating cells in the hind-limb muscle tissue might influence the results, the forelimb-muscle tissue was used for D2 analysis in this study. Muscle tissue was obtained and immediately stored in liquid nitrogen.
S. pneumoniae infection Acute pneumonia was induced as previously described (Boelen et al. 2008). Briefly, S. pneumoniae serotype 3 (American Type Culture Collection, Manassas, VA, USA) was grown in Todd Hewitt broth (Difco, Detroit, MI, USA) at $37^{\circ} \mathrm{C}$, harvested at midlogarithmic phase, and washed twice in sterile saline. Bacteria were then resuspended in sterile saline at a concentration of $5 \times 10^{4}$ colony-forming units $(\mathrm{CFU}) / 50 \mu \mathrm{l}$. Mice $(n=6)$ were lightly anesthetized by inhalation of isoflurane, and $50 \mu \mathrm{l}$ containing $5 \times 10^{4} \mathrm{CFU}$ was inoculated intranasally (i.n). Control mice received $50 \mu \mathrm{l}$ sterile saline i.n. The amount of $S$. pneumoniae bacteria inoculated was determined by plating serial dilutions of the inoculum onto sheep-blood agar plates and incubated at $37^{\circ} \mathrm{C}$ and $5 \% \mathrm{CO}_{2}$. CFUs were counted after $16 \mathrm{~h}$. Serum was stored at $-20{ }^{\circ} \mathrm{C}$ until analysis. Hind-limb muscle tissue was obtained after $48 \mathrm{~h}$ and immediately stored in liquid nitrogen. Both the studies were approved by the local animal welfare committee.

\section{Thyroid hormone levels}

Serum $T_{3}$ and $T_{4}$ were measured with in-house RIAs (Wiersinga \& Chopra 1982). To prevent inter-assay variation $\left(\mathrm{T}_{3}: 6 \cdot 2 \%\right.$ and $\mathrm{T}_{4}: 7 \cdot 3 \%$ ), all samples of one experiment were measured within the same assay (intra-assay variability $\mathrm{T}_{3}: 3 \cdot 6 \%$ and $\left.\mathrm{T}_{4}: 6 \cdot 6 \%\right)$.

\section{RNA isolation and RT-PCR}

Muscle mRNA was isolated on the Magna Pure (Roche Molecular Biochemicals) using the Magna Pure LC mRNA tissue kit and $\sim 25 \mathrm{mg}$ of tissue. The protocol and buffers supplied with the kit were followed. cDNA synthesis was performed using the first strand cDNA synthesis kit for RT-PCR with oligo d(T) primers (Roche Molecular Biochemicals). Real-Time PCR was performed using the Lightcycler (Roche Molecular Biochemicals). Lightcycler FastStart DNA Master ${ }^{\text {Plus }}$ SYBR Green I kit (Roche Molecular Biochemicals) was used, adding $50 \mathrm{ng}$ primers each (Biolegio, Nijmegen, The Netherlands). Primer pairs for hypoxanthine phosphoribosyl transferase (Hprt1), interleukin-1 $\beta$ (Il1b), Tnf, and D2 and D3 were previously described (Bouaboula et al. 1992, Sweet et al. 2001, Boelen et al. 2004, Kwakkel et al. 2008). We designed primer pairs for Wsb1 and Usp33 (Wsb1-forward: $5^{\prime}$-GCC AGC CTT GCT GAT GAT A-3', Wsb1-reverse: $5^{\prime}$-CCC AGC AGC TAA AAC ACT GC-3'; Usp33-forward: 5'-CTT TTC GAG GTT ATT CTC AGC AG-3', Usp33-reverse: $5^{\prime}$-GGC TCT TCC TCC ATT TCC AT- $\left.3^{\prime}\right)$. Primers were intron-spanning or genomic DNA contamination was tested using a cDNA synthesis reaction without the addition of reverse transcriptase. PCR programs were as follows: denaturation $10 \min 95^{\circ} \mathrm{C}, 40-45$ cycles of $0-10 \mathrm{~s} 95^{\circ} \mathrm{C}, 10 \mathrm{~s}$ annealing temperature, $15-20 \mathrm{~s} 72^{\circ} \mathrm{C}$. Annealing temperatures were: $54{ }^{\circ} \mathrm{C}$ for $\mathrm{Hprt} 1,55^{\circ} \mathrm{C}$ for $\mathrm{D} 2$, 
$62{ }^{\circ} \mathrm{C}$ for Tnf, D3, Wsb1, and Usp33, and $60{ }^{\circ} \mathrm{C}$ for Il1b. For quantification a standard curve was generated of a sequence-specific PCR-product ranging from $0 \cdot 01$ to $100 \mathrm{fg} / \mu \mathrm{l}$ (measurements taken during the exponential phase of the amplification). Samples were corrected for their mRNA content using Hprt1 as a housekeeping gene. Samples were individually checked for their PCR-efficiency (Ramakers et al. 2003). The median of the efficiency was calculated for each assay, samples that differed more than 0.05 of the efficiency median value were not taken into account. Aberrant PCR-efficiencies occurred randomly and therefore did not bias the results.

\section{Deiodinase activity}

Muscle D2 activity was measured as previously described (Mebis et al. 2007). Samples were homogenized on ice in 10 volumes of PED50 buffer $(0 \cdot 1 \mathrm{M}$ sodium phosphate, $2 \mathrm{mM}$ EDTA, and $50 \mathrm{mM}$ dithiothreitol $\mathrm{pH} 7 \cdot 2$ ) using a Polytron (Kinematica, Luzern, Switzerland). Homogenates were used immediately. Protein concentration was measured with the Bio-Rad protein assay using BSA as the standard following the manufacturer's instructions (Bio-Rad Laboratories). D2 activity was measured in duplicate, using $75 \mu \mathrm{l}$ ( $\approx 150 \mu$ g protein) homogenate incubated $4 \mathrm{~h}$ at $37^{\circ} \mathrm{C}$ in a final volume of $0.15 \mathrm{ml}$ with $1 \mathrm{nM} \mathrm{T}_{4}$ or $500 \mathrm{nM} \mathrm{T}_{4}$ with the addition of $\sim 2 \times 10^{5}$ c.p.m. $\left[3^{\prime} 5^{\prime}-{ }^{125} \mathrm{I}\right] \mathrm{T}_{4}$ in $0 \cdot 1 \mathrm{M}$ sodium phosphate, $2 \mathrm{mM}$ EDTA (PE) $/ 0 \cdot 5 \%$ BSA. Reactions were stopped by adding $0.15 \mathrm{ml}$ ice-cold ethanol. After centrifugation, $0 \cdot 125 \mathrm{ml}$ of the supernatant was added to $0 \cdot 125 \mathrm{ml}$ $0.02 \mathrm{M}$ ammonium acetate $(\mathrm{pH} 4)$, and $0.1 \mathrm{ml}$ of the mixture was applied to $4 \cdot 6 \times 250 \mathrm{~mm}$ Symmetry C18 column connected to a Waters HPLC system (Model 600E pump, Model 717 WISP autosampler, Waters, Etten-Leur, The Netherlands). Mobile phase A: $0.02 \mathrm{M}$ ammonium acetate $(\mathrm{pH} 4 \cdot 0)$, mobile phase B: acetonitril. The column was eluted with a linear gradient $(28-42 \% \mathrm{~B}$ in $15 \mathrm{~min})$ at a flow of $1.2 \mathrm{ml} / \mathrm{min}$. The activity of $\mathrm{T}_{4}$ and $\mathrm{T}_{3}$ in the eluate was measured online using a Radiomatic Flow-one/Beta scintillation detector (Packard, Meriden, CT, USA). Incubation with $500 \mathrm{nM} \mathrm{T} \mathrm{T}_{4}$ saturates D2, therefore D2 activity measured with the incubation with $1 \mathrm{nM} \mathrm{T}$ minus the incubation with $500 \mathrm{nM} \mathrm{T}_{4}$ represents true D2 activity. D2 activity was expressed as fmol generated $T_{3}$ per minute per gram muscle tissue.

Deiodinase type 3 Muscle D3 (listed as Dio3 in the MGI Database) activity was measured the same way as muscle D2 activity, with the following adaptations: incubation for $4 \mathrm{~h}$ at $37^{\circ} \mathrm{C}$ with $1 \mathrm{nM} \mathrm{T} \mathrm{T}_{3}$ or $500 \mathrm{nM} \mathrm{T}$ with the addition of $\sim 2 \times 10^{5}$ c.p.m. $\left[3^{\prime} 5^{\prime}-{ }^{125} \mathrm{I}\right] \mathrm{T}_{3}$ in PE. For each group, we included one $500 \mathrm{nM} \mathrm{T}_{3}$ incubation. Incubation with $500 \mathrm{nM} \mathrm{T} \mathrm{T}_{3}$ saturates D3, therefore D3 activity measured with the incubation with $1 \mathrm{nM} \mathrm{T}$ minus the incubation with $500 \mathrm{nM} \mathrm{T} \mathrm{T}_{3}$ represents true D3 activity. D3 activity was expressed as fmol generated 3,3'-diiodothyronine $\left(T_{2}\right)$ per minute per mg tissue.

\section{Western blotting}

Homogenates prepared for deiodinase measurement were immediately 1:1 mixed with freshly prepared protein dilution buffer $(250 \mathrm{mM}$ sucrose, $10 \%$ glycerol, $2 \mathrm{mM}$ phenylmethylsulphonyl fluoride, $4 \mathrm{mM} \mathrm{Na} 3 \mathrm{VO}_{4}, 40 \mathrm{mM}$ $\mathrm{NaF}, 2 \times$ Complete protease inhibitor cocktail (Roche Molecular Biochemicals). Protein content was measured and $25 \mu \mathrm{g}$ was loaded on a $10 \%$ SDS-PAGE gel. Gels were blotted on Immobilon-P transfer membrane (Millipore, Bedford, MA, USA). Blots were blocked with $3 \%$ casein in $\mathrm{TBS} / \mathrm{T}$, for $1 \mathrm{~h}$ at room temperature (RT). Primary antibodies were phospho-NFкB p65 (Ser536) (\#3033), phospho-p44/p42 MAP kinase (Thr202/Tyr204) (\#9101), phospho-c-jun (Ser63) (\#9261), and phospho-CREB (Ser133) (\#9191), goat-anti-rabbit-HRP (\#7074) (Cell Signaling Technology, Danvers, MA, USA). Primary antibodies were incubated for $1 \mathrm{~h}$ at $\mathrm{RT}$ followed by an overnight incubation at $4{ }^{\circ} \mathrm{C}$. Blots were washed three times 5 min with TBS/T. Following $1 \mathrm{~h}$ incubation at RT with secondary antibody goat-anti-rabbit-HRP, blots were washed again and detected with Lumi-Light chemiluminescent substrate (Roche Molecular Biochemicals). The emitted light was visualized and quantified on the Lumi-Imager (Roche Molecular Biochemicals). All antibodies were diluted 1:1000 in blocking buffer, except phospho-CREB, which is diluted 1:2000.

\section{Statistical analysis}

Normal distribution of the data was tested using the ShapiroWilk test. Statistical significance between turpentine and control treatment were evaluated using two-way ANOVA with two grouping factors (time and treatment). When not normally distributed, data were ranked before performing ANOVA. $P$ values in the figures represent the significant effect of the treatment. To test pair-wise comparisons ANOVA was followed by Students $t$-test when data was normally distributed or Mann-Whitney $U$ tests when not normally distributed. Symbols in the figures represent the pair-wise $P$ values. $P$ values $<0.05$ were considered statistically significant. Spearman's rank correlation tests were performed to test correlations. All tests were performed using SPSS (Chicago, IL, USA).

\section{Results}

\section{Muscle D2 expression}

Turpentine injection resulted in increased expression of muscle D2 mRNA and activity $(P<0 \cdot 01)$, compared to saline treated pair-fed controls, most prominent at day 1 and 2 after injection (Fig. 1A). In saline-treated pair-fed controls, D2 mRNA and activity decreased probably due to decreased food-intake. D2 activity in control groups was in some cases below detection limit. In contrast, muscle D2 mRNA decreased in muscle-tissue $48 \mathrm{~h}$ after $S$. pneumoniae infection, 

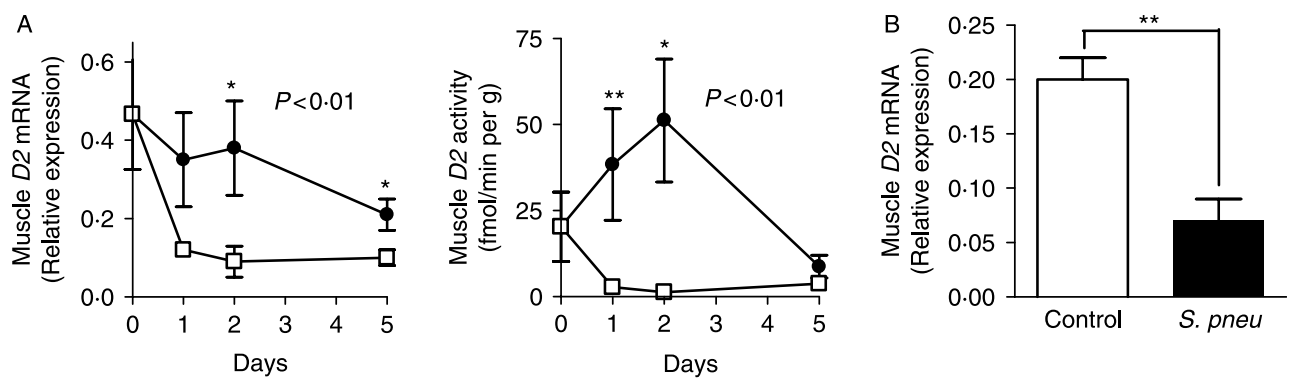

Figure 1 (A) Muscle $D 2$ mRNA and activity expression 1, 2, and 5 days after turpentine $(\bullet)$ or saline ( $\square$ ) injection. (B) Muscle D2 mRNA expression $48 \mathrm{~h}$ after $S$. pneumoniae infection (black bar) or saline-treated (white bar) controls. Mean values \pm S.E.M. $(n=4 / 6)$ are shown. $P$ values indicate differences between groups by nonparametric ANOVA. Symbols indicate differences evaluated by Mann-Whitney $U$ tests; ${ }^{*} P \leq 0 \cdot 05, * * P \leq 0 \cdot 01$.

compared to saline treated controls $(P<0 \cdot 01$; Fig. 1B). Muscle D2 activity was around the detection limit (2 above and 4 below the detection limit in each group) in muscle tissue of $S$. pneumoniae infected and control mice.

\section{Serum thyroid hormone levels}

Serum $\mathrm{T}_{4}$ and $\mathrm{rT}_{3}$ levels decreased $(P<0 \cdot 01) 1,2$ and 5 days after turpentine injection, whereas serum $\mathrm{T}_{3}$ did not change compared to pair-fed saline-treated controls (Fig. 2A). Muscle D2 mRNA expression did not correlate to serum $\mathrm{T}_{3}$. Serum $\mathrm{rT}_{3}$ was associated with muscle D2 activity $(r=-0.504$, $P<0 \cdot 01)$, while serum $\mathrm{T}_{4}$ was not.

After $S$. pneumoniae infection serum $\mathrm{T}_{4}$ decreased $(P<0 \cdot 01)$. Serum $\mathrm{T}_{3}$ and $\mathrm{rT}_{3}$ did not change (Fig. $2 \mathrm{~B}$ ). Serum $\mathrm{T}_{3}$ was not related to muscle $D 2$ mRNA expression.

\section{Muscle Wsb1 and Usp33 mRNA expression}

Ubiquitination promoting enzyme $W s b 1$ and de-ubiquitination enzyme Usp33 mRNA expression were evaluated. Muscle $W s b 1$ mRNA increased significantly 5 days after turpentine injection $(P<0 \cdot 05)$, whereas Usp33 mRNA did not change significantly (Fig. 3A). Wsb1 and Usp33 mRNA levels were not related to muscle D2 activity during turpentine induced inflammation. After S. pneumoniae infection muscle Wsb1 mRNA did not change, whereas Usp33 mRNA decreased compared to saline-treated controls (Fig. 3B).

\section{Muscle cytokine expression}

Muscle Tnf mRNA increased day 5 after turpentine injection compared to saline-treated, pair-fed controls, whereas muscle $I l 1 b$ did not (Fig. 4A). Muscle $I l 1 b$ or Tnf
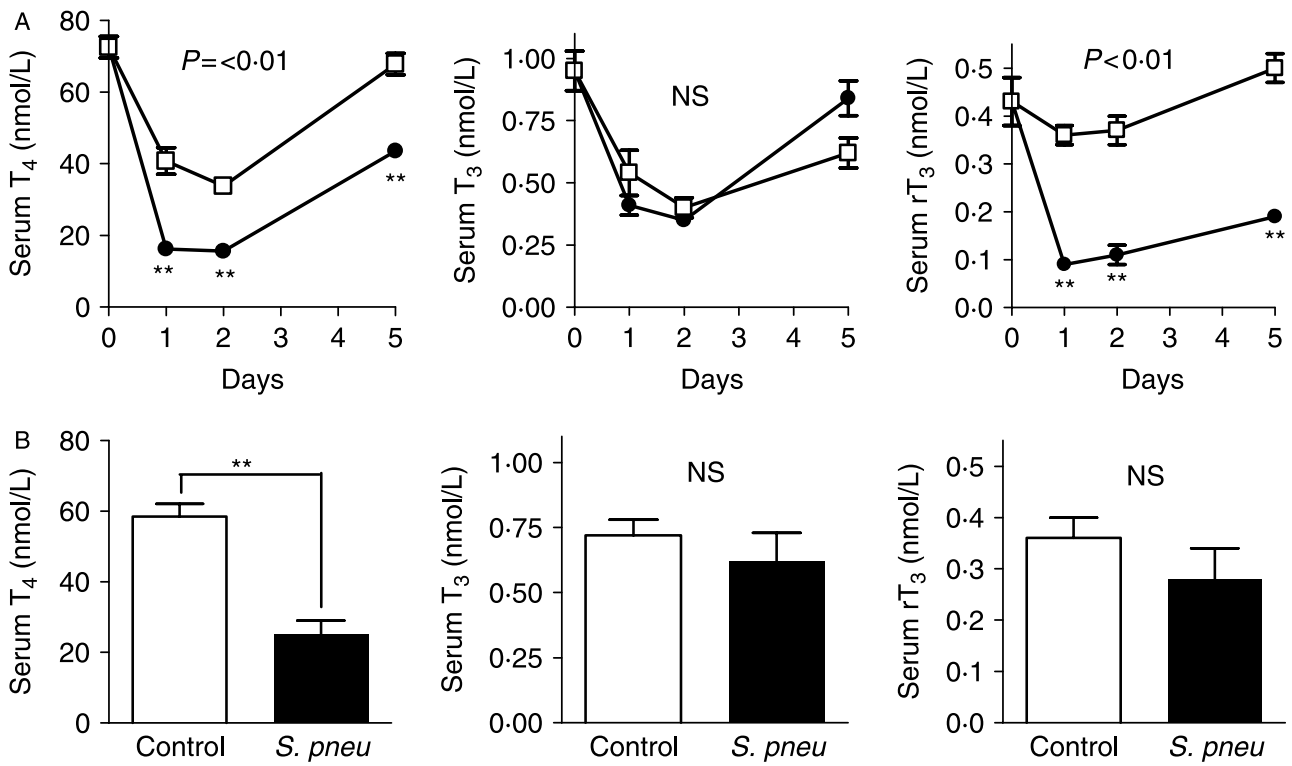

Figure 2 Serum $T_{4}, T_{3}$, and $r T_{3}$ levels. (A) 1, 2, and 5 days after turpentine (•) or saline ( $\square$ ) injection, (B) $48 \mathrm{~h}$ after $S$. pneumoniae infection (black bars) or saline-treated (white bars) controls. Mean values \pm S.E.M. $(n=4 / 6)$ are shown. $P$ values indicate differences between groups by nonparametric ANOVA. Symbols indicate differences evaluated by Mann-Whitney $U$ test; ${ }^{* *} P \leq 0 \cdot 01$. 

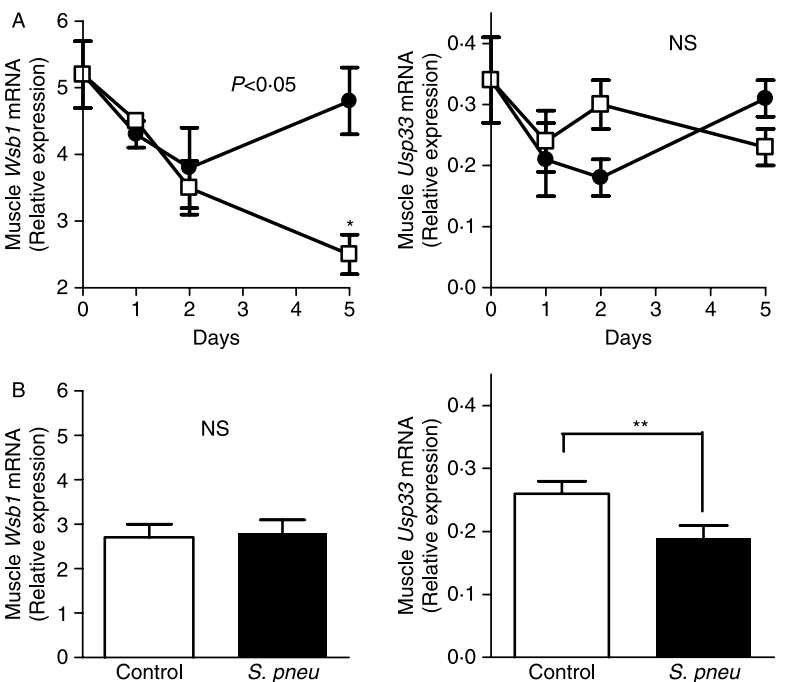

Figure 3 Muscle $W s b 1$ and Usp33 mRNA expression. (A) 1, 2, and 5 days after turpentine (O) or saline ( $\square$ ) injection, (B) $48 \mathrm{~h}$ after $S$. pneumoniae infection (black bars) or saline-treated (white bars) controls. Mean values \pm s.E.M. $(n=4 / 6)$ are shown. $P$ values indicate differences between groups by nonparametric ANOVA. Symbols indicate differences evaluated by Mann-Whitney $U$ test; ${ }^{*} P \leq 0 \cdot 05$, $* * P \leq 0 \cdot 01$.

cytokine expression is not related to D2 mRNA expression. After $S$. pneumoniae infection muscle $I l 1 b$ mRNA increased $(P<0 \cdot 01$; Fig. 4B) and was negatively correlated to D2 mRNA expression $(r=-0.691, P<0 \cdot 05)$. Muscle Tnf mRNA expression did not change significantly after $S$. pneumoniae infection and was not correlated to muscle D2 mRNA expression.

\section{Activation of signalling pathways}

Phosphorylated NFKB, c-jun, ERK1/2, and CREB were evaluated in muscle tissue by western blotting. After turpentine injection CREB was highly phosphorylated at day 1 and 2 (Fig. 5A) while NFKB (p65) and ERK1/2 did not differ compared to saline-treated pair-fed controls. The phosphorylation of CREB coincides with the observed increase in D2 expression after turpentine injection. No difference was observed in phosphorylation of CREB, NFKB or ERK1/2 after S. pneumoniae infection compared to saline-treated controls (Fig. 5B). Phosphorylated c-jun was not detectable in muscle tissue (data not shown).

\section{Muscle D3 expression}

Turpentine injection resulted in increased expression of muscle D 3 mRNA and activity $(P<0 \cdot 05)$, compared to saline treated pair-fed controls, most prominent at day 1 and 2 after injection (Fig. 6A). D3 activity in control groups was in most cases below detection limit. After $S$. pneumoniae infection muscle D3 mRNA did not change. Muscle D3 activity was below the detection limit in the saline controls, whereas three samples were positive after $S$. pneumoniae infection. However, the observed difference was not significantly different $(P=0 \cdot 056)$.

\section{Discussion}

We studied the association between muscle $D 2$ expression and D2 regulating factors in two different animal models of illness: turpentine-induced abscess in the hindlimb and S. pneumoniae infection. The animal models used differ in timing of the acute phase response and severity of illness. After turpentine injection in the hindlimb, an abscess is formed in the first 2 days, causing serious discomfort, fever, and decreased food-intake. Serum IL-6 and IL-1 are high during this early phase, whereas serum TNF $\alpha$ does not play a role. Five days after turpentine serum IL-1 and IL-6 decrease, temperature and food-intake return to normal and mice recover, although liver $I l 1 b \mathrm{mRNA}$ increases which is characteristic for the development of a systemic acute phase response (Boelen et al. 1996, 2005, Leon 2002, Elhija et al. 2006).

In contrast to turpentine induced inflammation, S. pneumoniae infection is lethal (Knapp et al. 2004). $S$. pneumoniae infection results in severe bronchopneumonia within 24 and $48 \mathrm{~h}$ after inoculation mice become septic (Boelen et al. 2008). Serum IL-1 and IL-6 increase rapidly after infection, whereas $\mathrm{TNF} \alpha$ is produced at a later stage
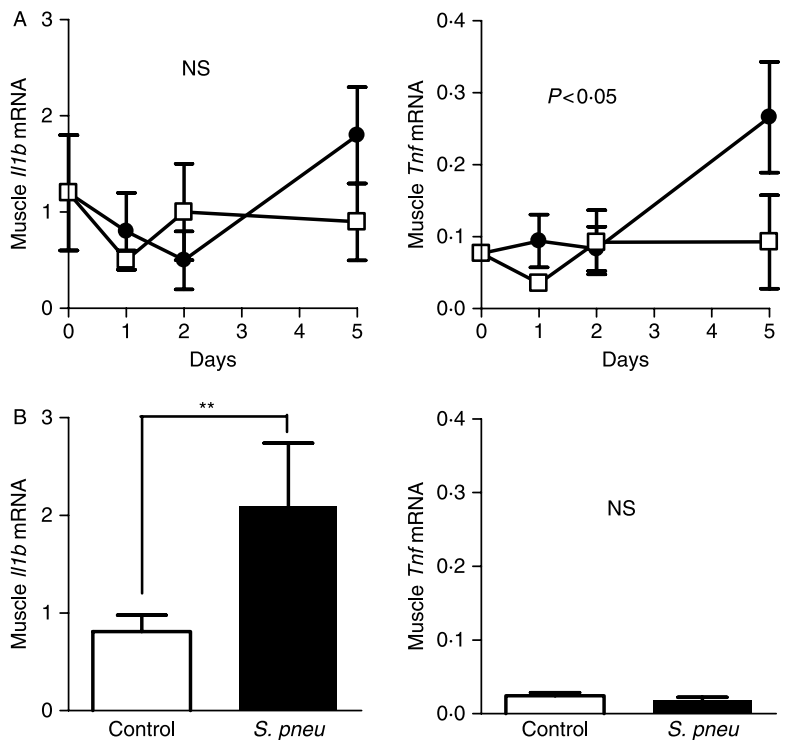

Figure 4 Muscle $\| 11 b$ and Tnf mRNA expression. (A) 1, 2, and 5 days after turpentine $(\mathbf{)})$ or saline $(\square)$ injection, (B) $48 \mathrm{~h}$ after $S$. pneumoniae infection (black bars) or saline-treated (white bars) controls. Mean values \pm S.E.M. $(n=4 / 6)$ are shown. $P$ values indicate differences between groups by nonparametric ANOVA. Symbols indicate differences evaluated by Mann-Whitney $U$ test; ${ }^{* *} P \leq 0 \cdot 01$. 
A
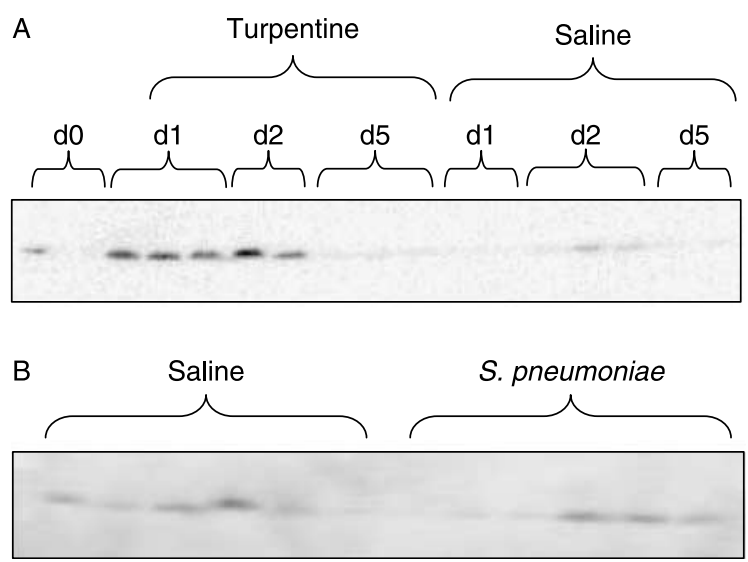

Figure 5 Representative western blot of phosphorylated CREB expression of (A) 1,2, and 5 days after turpentine or saline injection, (B) $48 \mathrm{~h}$ after $S$. pneumoniae infection or saline-treated controls.

(Bergeron et al. 1998). The difference in cytokine expression, acute phase response, and severity of illness between these two animal models suggests differential regulation of D2 expression. During turpentine-induced inflammation, D2 mRNA and activity increased compared to pair-fed controls, most prominently at day 1 and 2 , whereas after $S$. pneumoniae infection D2 mRNA decreased. The D2 increase compared to pair-fed controls during turpentine-induced inflammation is in line with increased D2 expression recently observed in skeletal muscle of ICU patients and in LPStreated mice (Mebis et al. 2007, Kwakkel et al. 2008), while decreased muscle D2 mRNA expression after S. pneumoniae
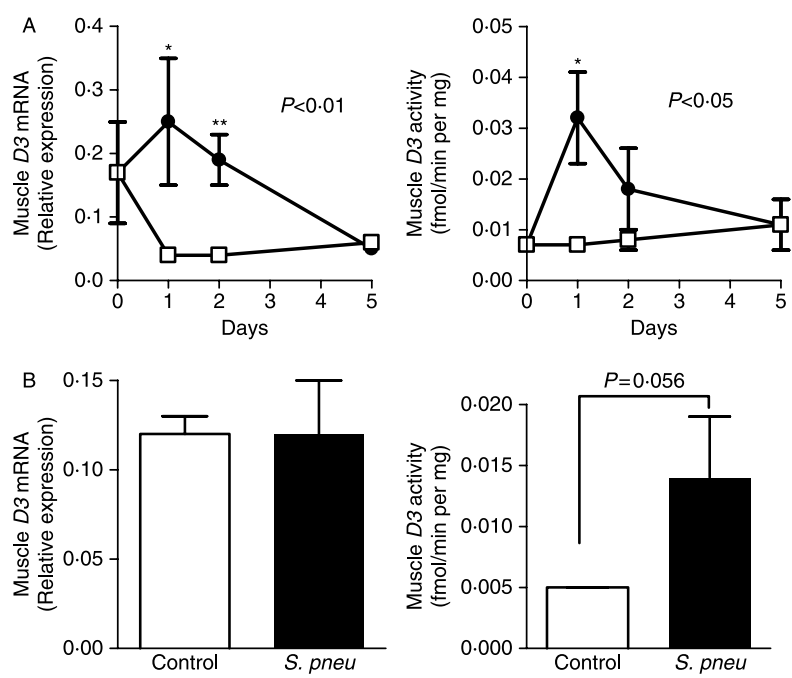

Figure 6 (A) Muscle D3 mRNA and activity expression 1, 2, and 5 days after turpentine $(-$ ) or saline $(\square)$ injection, (B) Muscle D3 mRNA and activity expression $48 \mathrm{~h}$ after $S$. pneumoniae infection (black bars) or saline-treated (white bars) controls. Mean values \pm S.E.M. $(n=4 / 6)$ are shown. $P$ values indicate differences between groups by nonparametric ANOVA. Symbols indicate differences evaluated by Mann-Whitney $U$ tests; ${ }^{*} P \leq 0 \cdot 05,{ }^{* *} P \leq 0 \cdot 01$. infection corresponds with previously reported D2 decrease in muscle tissue of septic patients (Rodriguez-Perez et al. 2008). Although it might be possible that the observed differences in D2 expression during illness in our animalmodels result from the different muscle origins, this seems unlikely because the D2 increase observed previously after LPS administration (Kwakkel et al. 2008) is similar in both muscle types (Kwakkel, unpublished observation).

D2 mRNA and activity are regulated by thyroid hormones; D2 mRNA and activity increases during hypothyroidism, while hyperthyroidism results in decreased D2 mRNA expression and activity, due to transcriptional $\left(\mathrm{T}_{3}\right)$ and translational $\left(\mathrm{T}_{4}\right.$ and $\left.\mathrm{rT}_{3}\right)$ regulation. However, thyroid hormone metabolism during illness differs from normal regulation (Wiersinga 2005). In both our animal models, no correlation between serum $\mathrm{T}_{3}$ and $\mathrm{T}_{4}$ levels and muscle D2 expression was observed. This is reminiscent to the $\mathrm{T}_{4}$-independent $\mathrm{D} 2$ activity increase in the mediobasal hypothalamus induced by LPS administration (Fekete et al. 2005). Factors involved in (de-)ubiquitination of D2 in our study did not correlate with D2 activity, although the observed increase in Wsb1 mRNA 5 days after turpentine coincides with a normalization of D2 activity. Inflammatory cytokines have profound effects on peripheral and central thyroid hormone metabolism (Boelen et al. 2006b). We studied muscle Il1 b and Tnf mRNA expression and the activation of three inflammatory pathways in muscle tissue.

After turpentine injection, Il1b and Tnf mRNA expression tended to increase after 5 days, which is in accordance with the declining muscle $D 2$ expression 5 days after turpentine injection as $\mathrm{TNF} \alpha$ decreases muscle $\mathrm{D} 2$ mRNA expression in vitro (Hosoi et al. 1999). Furthermore, we observed increased $I l 1 b$ mRNA expression in muscle tissue of $S$. pneumoniae infected mice, which was inversely correlated to D2 mRNA expression. However, the observed alterations in D2 expression appeared not to be mediated via activation of the inflammatory pathways NFKB, ERK1/2, or AP-1.

The decreased D2 expression after $S$. pneumoniae infection might also be due to diminished food-intake, as D2 expression decreases after fasting in healthy humans (Heemstra et al. 2009). In addition, D2 mRNA expression also decreased in the pair-fed controls of the turpentine experiment.

cAMP activation is a potent stimulator of $\mathrm{D} 2$, both preand post-transcriptionally (Hosoi et al. 1999, Bartha et al. 2000, Dentice et al. 2007). We evaluated phosphorylated CREB expression in muscle tissue as a marker for cAMP activation. CREB was highly phosphorylated in muscle tissue within $48 \mathrm{~h}$ after turpentine injection, which coincides with the marked increase of D2 expression compared with pair-fed controls, suggesting a dominant role of the cAMP pathway in the observed $D 2$ increase.

Increased D2 activity theoretically results in increased $\mathrm{T}_{3}$ production, which is not reflected in increased serum 
$\mathrm{T}_{3}$ concentrations, suggesting that $\mathrm{D} 2$ contribution to systemic $\mathrm{T}_{3}$ levels is quantitatively limited. To evaluate the physiological implications of the observed D2 alterations during illness, muscle D3 expression was evaluated. After S. pneumoniae infection, D3 mRNA did not change, while $D 3$ activity tended to increase, however the activity measured was very low. In contrast, muscle $D 3$ mRNA and activity increased after turpentine injection compared to pair-fed controls. The increase of muscle D3 during illness has previously been reported (Rodriguez-Perez et al. 2008).

During turpentine induced inflammation, the increase in muscle $D 2$ and $D 3$ compared with pair-fed controls coincides with the increased body temperature and decreased food-intake observed during this phase of inflammation (Leon 2002). Cooper \& Rothwell (1991) showed increased $\beta$-adrenergic-dependent oxygen-consumption in the first $36 \mathrm{~h}$ after turpentine injection. Sympathetic stimulation of cultured human skeletal muscle cells results in activation of the cAMP pathway and in upregulation of D2 in muscle cells (Hosoi et al. 1999), subsequently followed by increased mitochondrial activity and thus increased oxygenconsumption (Watanabe et al. 2006).

Because both the measured D2 and D3 activities are very low, a local effect in the skeletal muscle seems more likely than an effect on serum thyroid hormone levels. The simultaneous upregulation of $D 2$ and $D 3$ theoretically only leads to the formation of $3,3^{\prime}-\mathrm{T}_{2}$, which might be able to activate the mitochondrial enzyme cytochrome $c$ oxidase (Goglia et al. 1994, Lanni et al. 1994) thereby also increasing oxygen consumption. A shortage of $3,3^{\prime}-\mathrm{T}_{2}$ might result in mitochondrial dysfunction, which is thought to play a role in the pathogenesis of sepsis (Fredriksson et al. 2006, Zang et al. 2007). Adding exogenous cytochrome $c$ oxidase improves cardiomyocyte mitochondrial function in an animal model of sepsis (Levy \& Deutschman 2007). These speculations need further investigation in order to consider the role of D2 and D3 in muscle tissue as a regulator of muscle mitochondrial activity during illness.

In conclusion, muscle D2 expression is differentially regulated during illness, probably related to differences in the inflammatory response and type of pathology. D2 mRNA and activity increase in skeletal muscle during the acute phase of chronic inflammation compared to pair-fed controls probably due to activation of the cAMP pathway. In contrast, muscle D2 mRNA decreases $48 \mathrm{~h}$ after a severe bacterial infection, which is associated with local $I l 1 \mathrm{~b}$ mRNA expression and might also be due to diminished food-intake. The observed alterations in muscle D2 and D3 might result in changes in local $3,3^{\prime}-T_{2}$ concentrations and thereby affect mitochondrial activity.

\section{Declaration of interest}

The authors declare that there is no conflict of interest that could be perceived as prejudicing the impartiality of the research reported.

\section{Funding}

This research did not receive any specific grant from any funding agency in the public, commercial or not-for-profit sector.

\section{Acknowledgements}

We would like to thank J Daalhuizen (Department of Experimental Internal Medicine, Academic Medical Center, Amsterdam) for expert biotechnical assistance; Ing E Johannesma-Brian, and Drs E Endert (Department of Clinical Chemistry, Laboratory of Endocrinology, Academic Medical Center, Amsterdam) for measuring serum thyroid hormones.

\section{References}

Bartha T, Kim SW, Salvatore D, Gereben B, Tu HM, Harney JW, Rudas P \& Larsen PR 2000 Characterization of the $5^{\prime}$-flanking and $5^{\prime}$-untranslated regions of the cyclic adenosine $3^{\prime}, 5^{\prime}$-monophosphate-responsive human type 2 iodothyronine deiodinase gene. Endocrinology 141 229-237.

Bergeron Y, Ouellet N, Deslauriers AM, Simard M, Olivier M \& Bergeron MG 1998 Cytokine kinetics and other host factors in response to pneumococcal pulmonary infection in mice. Infection and Immunity 66 912-922.

Bianco AC \& Kim BW 2006 Deiodinases: implications of the local control of thyroid hormone action. Journal of Clinical Investigation 116 2571-2579.

Boelen A, Maas MA, Lowik CW, Platvoet MC \& Wiersinga WM 1996 Induced illness in interleukin-6 (IL-6) knock-out mice: a causal role of IL-6 in the development of the low 3,5,3'-triiodothyronine syndrome. Endocrinology 137 5250-5254.

Boelen A, Kwakkel J, Thijssen-Timmer DC, Alkemade A, Fliers E \& Wiersinga WM 2004 Simultaneous changes in central and peripheral components of the hypothalamus-pituitary-thyroid axis in lipopolysaccharide-induced acute illness in mice. Journal of Endocrinology 182 315-323.

Boelen A, Kwakkel J, Alkemade A, Renckens R, Kaptein E, Kuiper G, Wiersinga WM \& Visser TJ 2005 Induction of type 3 deiodinase activity in inflammatory cells of mice with chronic local inflammation. Endocrinology 146 5128-5134.

Boelen A, Kwakkel J, Vos XG, Wiersinga WM \& Fliers E 2006 a Differential effects of leptin and refeeding on the fasting-induced decrease of pituitary type 2 deiodinase and thyroid hormone receptor $\beta 2$ mRNA expression in mice. Journal of Endocrinology 190 537-544.

Boelen A, Wiersinga WM \& Kohrle J $2006 b$ Contributions of cytokines to nonthyroidal illness. Current Opinion in Endocrinology and Diabetes 13 444-450 (Ref type: Journal (Full)).

Boelen A, Boorsma J, Kwakkel J, Wieland CW, Renckens R, Visser TJ, Fliers E \& Wiersinga WM 2008 Type 3 deiodinase is highly expressed in infiltrating neutrophilic granulocytes in response to acute bacterial infection. Thyroid 18 1095-1103.

Bouaboula M, Legoux P, Pessegue B, Delpech B, Dumont X, Piechaczyk M, Casellas P \& Shire D 1992 Standardization of mRNA titration using a polymerase chain reaction method involving co-amplification with a multispecific internal control. Journal of Biological Chemistry 267 21830-21838.

Burmeister LA, Pachucki J \& St Germain DL 1997 Thyroid hormones inhibit type 2 iodothyronine deiodinase in the rat cerebral cortex by both pre- and posttranslational mechanisms. Endocrinology 138 5231-5237.

Cooper AL \& Rothwell NJ 1991 Mechanisms of early and late hypermetabolism and fever after localized tissue injury in rats. American Journal of Physiology 261 E698-E705.

Dentice M, Luongo C, Huang S, Ambrosio R, Elefante A, Mirebeau-Prunier D, Zavacki AM, Fenzi G, Grachtchouk M, Hutchin M et al. 2007 Sonic 
hedgehog-induced type 3 deiodinase blocks thyroid hormone action enhancing proliferation of normal and malignant keratinocytes. PNAS 104 14466-14471.

Elhija MA, Lunenfeld E \& Huleihel M 2006 Induction of IL-1, in the testes of adult mice, following subcutaneous administration of turpentine. American Journal of Reproductive Immunology 55 136-144.

Fekete C, Sarkar S, Christoffolete MA, Emerson CH, Bianco AC \& Lechan RM 2005 Bacterial lipopolysaccharide (LPS)-induced type 2 iodothyronine deiodinase (D2) activation in the mediobasal hypothalamus $(\mathrm{MBH})$ is independent of the LPS-induced fall in serum thyroid hormone levels. Brain Research 1056 97-99.

Fredriksson K, Hammarqvist F, Strigard K, Hultenby K, Ljungqvist O, Wernerman J \& Rooyackers O 2006 Derangements in mitochondrial metabolism in intercostal and leg muscle of critically ill patients with sepsis-induced multiple organ failure. American Journal of Physiology. Endocrinology and Metabolism 291 E1044-E1050.

Gereben B \& Salvatore D 2005 Pretranslational regulation of type 2 deiodinase. Thyroid 15 855-864.

Goglia F, Lanni A, Barth J \& Kadenbach B 1994 Interaction of diiodothyronines with isolated cytochrome $c$ oxidase. FEBS Letters 346 295-298.

Heemstra KA, Soeters MR, Fliers E, Serlie MJ, Burggraaf J, van Doorn MB, van der Klaauw AA, Romijn JA, Smit JW, Corssmit EP et al. 2009 Type 2 iodothyronine deiodinase in skeletal muscle: effects of hypothyroidism and fasting. Journal of Clinical Endocrinology and Metabolism 94 2144-2150.

Hosoi Y, Murakami M, Mizuma H, Ogiwara T, Imamura M \& Mori M 1999 Expression and regulation of type II iodothyronine deiodinase in cultured human skeletal muscle cells. Journal of Clinical Endocrinology and Metabolism 84 3293-3300.

Knapp S, Hareng L, Rijneveld AW, Bresser P, van der Zee JS, Florquin S, Hartung T \& van der Poll T 2004 Activation of neutrophils and inhibition of the proinflammatory cytokine response by endogenous granulocyte colony-stimulating factor in murine pneumococcal pneumonia. Journal of Infectious Diseases 189 1506-1515.

Kohrle J 2000 The selenoenzyme family of deiodinase isozymes controls local thyroid hormone availability. Reviews in Endocrine and Metabolic Disorders 1 49-58.

Kwakkel J, Chassande O, van Beeren HC, Wiersinga WM \& Boelen A 2008 Lacking thyroid hormone receptor beta gene does not influence alterations in peripheral thyroid hormone metabolism during acute illness. Journal of Endocrinology 197 151-158.

Lanni A, Moreno M, Lombardi A \& Goglia F 1994 Rapid stimulation in vitro of rat liver cytochrome oxidase activity by 3,5-diiodo-L-thyronine and by 3,3'-diiodo-L-thyronine. Molecular and Cellular Endocrinology 99 89-94.

Leon LR 2002 Invited review: cytokine regulation of fever: studies using gene knockout mice. Journal of Applied Physiology 92 2648-2655.

Levy RJ \& Deutschman CS 2007 Cytochrome $c$ oxidase dysfunction in sepsis. Critical Care Medicine 35 S468-S475.
Maia AL, Kim BW, Huang SA, Harney JW \& Larsen PR 2005 Type 2 iodothyronine deiodinase is the major source of plasma $\mathrm{T}_{3}$ in euthyroid humans. Journal of Clinical Investigation 115 2524-2533.

Mebis L, Langouche L, Visser TJ \& Van den Berghe G 2007 The type II iodothyronine deiodinase is up-regulated in skeletal muscle during prolonged critical illness. Journal of Clinical Endocrinology and Metabolism 92 3330-3333.

Ramakers C, Ruijter JM, Deprez RH \& Moorman AF 2003 Assumption-free analysis of quantitative real-time polymerase chain reaction (PCR) data. Neuroscience Letters 339 62-66.

Rodriguez-Perez A, Palos-Paz F, Kaptein E, Visser TJ, Dominguez-Gerpe L, varez-Escudero J \& Lado-Abeal J 2008 Identification of molecular mechanisms related to nonthyroidal illness syndrome in skeletal muscle and adipose tissue from patients with septic shock. Clinical Endocrinology 68 $821-827$

Sagar GD, Gereben B, Callebaut I, Mornon JP, Zeold A, da Silva WS, Luongo C, Dentice M, Tente SM, Freitas BC et al. 2007 Ubiquitinationinduced conformational change within the deiodinase dimer is a switch regulating enzyme activity. Molecular and Cellular Endocrinology 27 4774-4783.

Sweet MJ, Leung BP, Kang D, Sogaard M, Schulz K, Trajkovic V, Campbell CC, Xu D \& Liew FY 2001 A novel pathway regulating lipopolysaccharide-induced shock by ST2/T1 via inhibition of Toll-like receptor 4 expression. Journal of Immunology 166 6633-6639.

Watanabe M, Houten SM, Mataki C, Christoffolete MA, Kim BW, Sato H, Messaddeq N, Harney JW, Ezaki O, Kodama T et al. 2006 Bile acids induce energy expenditure by promoting intracellular thyroid hormone activation. Nature 439 484-489.

Wiersinga WM 2005 Nonthyroidal illness. In The Thyroid, edn 8, pp 246-263. Eds LE Braverman \& RD Utiger. Philadelphia: Lippincott.

Wiersinga WM \& Chopra IJ 1982 Radioimmunoassay of thyroxine $\left(\mathrm{T}_{4}\right), 3,5,3^{\prime}$-triiodothyronine $\left(\mathrm{T}_{3}\right), 3,3^{\prime}, 5^{\prime}$-triiodothyronine (reverse $\mathrm{T}_{3}, \mathrm{rT}_{3}$ ), and 3,3'-diiodothyronine $\left(\mathrm{T}_{2}\right)$. Methods in Enzymology 84 272-303.

Zang Q, Maass DL, Tsai SJ \& Horton JW 2007 Cardiac mitochondrial damage and inflammation responses in sepsis. Surgical Infections 8 41-54.

Zeold A, Doleschall M, Haffner MC, Capelo LP, Menyhert J, Liposits Z, da Silva WS, Bianco AC, Kacskovics I, Fekete C et al. 2006 Characterization of the nuclear factor-kappa $\mathrm{B}$ responsiveness of the human dio2 gene. Endocrinology 147 4419-4429.

Received in final form 3 July 2009

Accepted 5 August 2009

Made available online as an Accepted Preprint 5 August 2009 